University of Nebraska - Lincoln

DigitalCommons@University of Nebraska - Lincoln

\title{
Isolation and characterization of 11 polymorphic microsatellite loci in collared lizards (Crotaphytus collaris)
}

\author{
Delbert W. Hutchison \\ Whitman College, Walla Walla,WA, hutchidw@whitman.edu \\ Jared L. Strasburg \\ Washington University, St. Louis, MO \\ Jennifer A. Brisson \\ University of Nebraska-Lincoln, jennifer.brisson@rochester.edu \\ Shawn Cummings \\ St. Louis, MO
}

Follow this and additional works at: https://digitalcommons.unl.edu/bioscifacpub

Part of the Life Sciences Commons

Hutchison, Delbert W.; Strasburg, Jared L.; Brisson, Jennifer A.; and Cummings, Shawn, "Isolation and characterization of 11 polymorphic microsatellite loci in collared lizards (Crotaphytus collaris)" (2004). Faculty Publications in the Biological Sciences. 73.

https://digitalcommons.unl.edu/bioscifacpub/73

This Article is brought to you for free and open access by the Papers in the Biological Sciences at DigitalCommons@University of Nebraska - Lincoln. It has been accepted for inclusion in Faculty Publications in the Biological Sciences by an authorized administrator of DigitalCommons@University of Nebraska - Lincoln. 
Published in Molecular Ecology Notes 4 (2004), pp. 554-556; doi: 10.1111/j.1471-8286.2004.00730.x Copyright (C) 2004 Blackwell Publishing Ltd.

Used by permission.

Submitted March 26, 2004; revised May 28, 2004; accepted May 28, 2004.

PRIMER NOTE

\title{
Isolation and characterization of 11 polymorphic microsatellite loci in collared lizards (Crotaphytus collaris)
}

\author{
Delbert W. Hutchison, ${ }^{*}$ Jared L. Strasburg, ${ }^{\dagger}$ Jennifer A. Brisson, ${ }^{\dagger}$ and Shawn Cummings ${ }^{\ddagger}$ \\ * Biology Department, Whitman College, Walla Walla, WA, 99362, USA, \\ ${ }^{\dagger}$ Department of Biology, Campus Box 1137, Washington University, St. Louis, MO 63130, USA, \\ ‡7205 Delta Avenue, St. Louis, MO, 63117, USA \\ Corresponding author - D. W. Hutchinson, fax 509 527-5904, email hutchidw@whitman.edu
}

\begin{abstract}
We identified 11 polymorphic microsatellite loci in collared lizards (Crotaphytus collaris). Polymorphism assessment in 512 individuals from 52 populations sampled across much of the species distribution revealed a fairly high degree of genetic diversity (six to 20 alleles per locus) and a wide range of average expected heterozygosity values (0.143-0.530). We found no evidence for linkage, very few deviations from HW expectation (two of 572 possible population/locus analyses) and thus no evidence for null alleles. There was a tendency for reduced polymorphism towards the northern periphery.
\end{abstract}

Keywords: Crotaphytus collaris, genetic variation, microsatellites, peripheral populations, population structure

Collared lizards (Crotaphytus collaris) are mediumsized heliothermic predators that inhabit rocky outcrops throughout their extensive range from the southwestern US and northern Mexico eastward through Oklahoma into the Flint Hills of Kansas and the Ozark Plateau of southern Missouri and northern Arkansas (McGuire 1996). Environmental conditions important to collared lizard survival and reproductive fitness vary widely across this geographical expanse. As a result, populations face varying selective and demographic forces in different parts of the range-making this an interesting group within which to investigate genetic structure (Hranitz \& Baird 2000; Campbell \& McCoy 2002), regional patterns of variability (Hutchison 2003) or the effects of habitat degradation (Templeton et al. 2001; Brisson et al. 2003). These animals also make excellent subjects for investigating social behavior or reproductive success due to dramatic sexual dimorphism in coloration, behavior, and territoriality (Baird et al. 1996).

Access to polymorphic microsatellite loci would greatly enhance the effectiveness of any of these investigations. To this end, we isolated $20 \mu \mathrm{g}$ of whole genomic DNA from a single collared lizard sampled in southwestern Missouri using standard phenol-chloroform extraction (Bruford et al. 1992). This DNA was used to construct two libraries, one nonenriched and one enriched. For the nonenriched library (described in Hutchison 1997), the DNA was digested with BamHI, size sorted (200-600 bp), ligated into pUC19 vector and transformed into DH5a cells. Subsequent colonies were screened twice with $\mathrm{CA}_{8} \mathrm{CAC}_{5}$ and $\mathrm{GACA}_{4}$ oligonucleotides to yield loci Orig6, Orig7, Orig11, Orig21, Orig24, Orig25, and Orig26 (from the original screening) and N5 (from the second screening). Construction of the enriched library followed a protocol designed by S. Cummings based on instructions provided with the streptavidin-coated magnetic beads (Promega ${ }^{\mathrm{TM}}$ ) with frequent reference to Sambrook et al. (1989). Whole genomic DNA was digested with Sau3AI, ligated into pUC19 vector and subjected to polymerase chain reaction (PCR) with pUC19 primers 1224 and 1233. Product was mixed with streptavidin-coated magnetic beads attached to oligonucleotides $\mathrm{CAG}_{5}$ or $\mathrm{CCT}_{5}$ to locate PCR products with these motifs. After separation from the beads, the products were again digested with Sau3AI, ligated back into pUC19 vectors and transformed into DH5a cells. Resulting "enriched" colonies were harvested and sequenced to identify loci Enri3, Enri21 and Enri48. For all 11 loci, primers flanking the microsatellite repeats (Table 1) were designed using oligo shareware and guidelines in Hoelzel \& Green (1992). 
Table 1. Temp (PCR annealing temperature), Buffers (PCR buffer; see below), Notes (locus-specific information; see below), $n$ (number of individuals surveyed for variability); $H_{\mathrm{O}}$ and $H_{\mathrm{E}}$ (observed and expected heterozygosity values, respectively, averaged across all populations)

\begin{tabular}{|c|c|c|c|c|c|c|c|c|c|c|}
\hline Locus & Primer Sequence (bp) & Motif & $\begin{array}{l}\text { Temp } \\
\left({ }^{\circ} \mathrm{C}\right) \quad \mathrm{B}\end{array}$ & Buffer & $\begin{array}{l}\text { \# alleles } \\
\text { (size range) }\end{array}$ & $\begin{array}{c}\text { Notes } \\
(1-4)\end{array}$ & $n$ & $H_{\mathrm{O}}$ & $H_{\mathrm{E}}$ & GenBank \# \\
\hline Orig6 & $\begin{array}{l}\text { For: AGGACACAAACATTCTTATC (20) } \\
\text { Rev: TCTGAGTATTCCTTGCTT (18) }\end{array}$ & $\begin{array}{l}\mathrm{CA}_{9} \\
\text { perfect }\end{array}$ & 46 & $\mathrm{C}$ & $7(138-150)$ & 1 & 441 & 0.265 & 0.348 & AY567818 \\
\hline Orig7 & $\begin{array}{l}\text { For: AGGTTGTGGTCTGTAGCA (18) } \\
\text { Rev: GGATCTGTCCCAATAATG (18) }\end{array}$ & $\begin{array}{l}\mathrm{CA}_{24} \\
\text { imperfect }\end{array}$ & 55 & B & $16(199-229)$ & 2 & 208 & 0.222 & 0.270 & AY567819 \\
\hline Orig11 & $\begin{array}{l}\text { For: CACTATAAGATGTAGCACTTGC (22) } \\
\text { Rev: GGTAAGCACCAGATTGAGC (19) }\end{array}$ & $\begin{array}{l}\mathrm{CA}_{8} \\
\text { perfect }\end{array}$ & 56 & $\mathrm{D}$ & 7 (169-182) & & 256 & 0.091 & 0.162 & AY567820 \\
\hline Orig24 & $\begin{array}{l}\text { For: AGTTGAACTCGATGCTCT (18) } \\
\text { Rev: ATTGAACCCATGGTAAAG (18) }\end{array}$ & $\begin{array}{l}\mathrm{GACA}_{10} \\
\text { imperfect }\end{array}$ & 52 & $\mathrm{D}$ & $16(144-204)$ & 4 & 276 & 0.323 & 0.400 & AY567822 \\
\hline Orig25 & $\begin{array}{l}\text { For: AGCCTTTACTGTGAGACCCA (20) } \\
\text { Rev: TCATGAAATGAAGCAAAATTAATAATA (27) }\end{array}$ & $\begin{array}{l}\mathrm{ATT}_{10} \\
\text { perfect }\end{array}$ & 51 & $\mathrm{D}$ & $12(109-154)$ & 1,4 & 313 & 0.354 & 0.417 & AY567822 \\
\hline Enr21 & $\begin{array}{l}\text { For: AGGAAGGCTCAAAGGTTAC (19) } \\
\text { Rev: ATTTCACACAGGAGGAGGAGG (21) }\end{array}$ & $\begin{array}{l}\mathrm{CCT}_{6} \\
\text { perfect }\end{array}$ & 60 & $\mathrm{D}$ & $6(99-114)$ & & 453 & 0.378 & 0.350 & AY567825 \\
\hline Enr48 & $\begin{array}{l}\text { For: TTTGTTCTTATTTTACTTGCGT (22) } \\
\text { Rev: AGGTATTGTGCTGTCTGAGG (20) }\end{array}$ & $\begin{array}{l}\mathrm{CA}_{13} \\
\text { perfect }\end{array}$ & 50 & A & 11 (107-127) & & 394 & 0.412 & 0.530 & AY567826 \\
\hline N5 & $\begin{array}{l}\text { For: CTGCCATATCATGAAGGGTG (20) } \\
\text { Rev: AATCAGCACACTGGGAAAG (19) }\end{array}$ & $\begin{array}{l}\mathrm{AT}_{16} \\
\text { perfect }\end{array}$ & 56 & $\mathrm{~J}$ & 17 (166-198) & 2 & 106 & 0.070 & 0.143 & AY567827 \\
\hline
\end{tabular}

Buffers: $\quad$ A - $200 \mathrm{~mm}$ Tris (pH 8.4), $250 \mathrm{~mm} \mathrm{KCl}, 15 \mathrm{~mm} \mathrm{MgCl}_{2}$

B - $200 \mathrm{~mm}$ Tris (pH 8.4), $250 \mathrm{~mm} \mathrm{KCl}, 25 \mathrm{~mm} \mathrm{MgCl}_{2}$

C - $200 \mathrm{~mm}$ Tris (pH 8.4), $500 \mathrm{~mm} \mathrm{KCl}, 15 \mathrm{~mm} \mathrm{MgCl}_{2}$

$\mathrm{D}-200 \mathrm{~mm}$ Tris (pH 8.4), $500 \mathrm{~mm} \mathrm{KCl}, 25 \mathrm{~mm} \mathrm{MgCl}_{2}$

$\mathrm{J}$ - $200 \mathrm{~mm}$ Tris (pH 9.2), $250 \mathrm{~mm} \mathrm{KCl}, 25 \mathrm{~mm} \mathrm{MgCl}_{2}$

Notes: $\quad 1=$ Poly A (add 30 minute, $72^{\circ} \mathrm{C}$ extension)

$2=$ Stutters, but readable since one peak much higher

$3=$ TD refers to touchdown PCR

$4=$ Physically linkage between loci 25 and 25 (no evidence of linkage disequilibrium)

Microsatellite loci were amplified using locus-specific conditions optimized for buffer, annealing temperature, and amplification cycles (Table 1). Fragments were amplified with fluorescently labelled forward primers and visualized using a BaseStation DNA Fragment Analyzer (MJ Research). Polymorphism was assessed using genomic DNA isolated from 512 collared lizards sampled at 52 sites across the species range (mean $=8.13$ animals/population). All 11 loci reported here were polymorphic (six to 20 alleles per locus) and amplified reliably, although there was variability in their performance. Loci Orig6, Orig25 and Enri3 exhibited a tendency to form poly-A tails. Fortunately, this is remedied by adding a 30 minute extension of $72^{\circ} \mathrm{C}$ at the end of the PCR run. Loci Orig7 and N5 stuttered, but in each case the true band is much greater in amplitude than false bands. Population analyses with the GDA computer program (Lewis \& Zaykin 1996), revealed a range of average heterozygosity values $(0.143-0.530)$ across all 52 populations. Furthermore, no linkage disequilibrium was evident between any of the loci, despite the fact that Loci Orig24 and Orig25 are only separated by 138 base pairs. Bonferroni analyses (Rice 1989) showed only two populations, of 572 possible population/locus combinations, deviated significantly from Hardy-Weinberg expectations, thus giving little evidence for null alleles (Chakraborty et al. 1992).

Workers interested in using these loci should be aware of potential geographical trends in polymorphism in some of the loci. For example, although all loci were variable across the species range, nine (all but Orig25 and N5) exhibited lower levels of heterozygosity towards the northern periphery of the range. However, correlation analyses between levels of heterozygosity and latitude showed this trend was significant (5\% level) for only six loci (Orig6, Orig11, Orig21, Orig24, Orig26, and Enri21), while only three remained significant after Bonferroni analyses (Orig11, Orig24, and Orig26). 
Thus, these three loci may prove less useful than others as measures of genetic variability in peripherally located populations.

\section{Acknowledgments}

This work was funded by a National Science Foundation grant to Alan R. Templeton (DEB-9610219), an NSF Research Opportunity Award to DWH (\#DEB-0108874-002), and Howard Hughes Medical Institute Predoctoral Fellowships to JLS and JAB. We also wish to thank the Missouri Departments of Conservation and Natural Resources.

\section{References}

Baird T. A., Acree M. A., Sloan C. L. (1996) Age and genderrelated differences in the social behavior and mating success of free-living collared lizards, Crotaphytus collaris. Copeia 1996: 2, 336- 347.

Brisson J. A., Strasburg J. L., Templeton A. R. (2003) Impact of fire management on the ecology of collared lizard (Crotaphytus collaris) populations living on the Ozark Plateau. Animal Conservation, 6, 247-254.

Bruford M. W., Hanotte O., Brookfield J. F. Y., Burke T. (1992) Single-locus and multilocus DNA fingerprinting. In: Molecular Genetic Analyses of Populations: a Practical Approach (ed. Hoelzel AR), pp. 225-266. IRL Press, Oxford.

Campbell J. H., McCoy J. K. (2002) Mitochondrial DNA analysis of gene flow among six populations of collared lizards (Crotaphytus collaris) in west central Texas. Texas Journal of Science, 54, 151-162.

Chakraborty R., De Andrade M., Daiger S. P., Budowle R. (1992) Apparent heterozygosity deficiencies observed in DNA typing data and their implications in forensic applications. Annals of Human Genetics, 56, 45-57.
Hoelzel A. R., Green A. (1992) Analysis of population-level variation by sequencing PCR- amplified DNA. In: Molecular Genetic Analyses of Populations: a Practical Approach (ed. Hoelzel AR), pp. 159-187. IRL Press, Oxford.

Hranitz J. M., Baird T. A. (2000) Effective population size and genetic structure of a population of collared lizards, Crotaphytus collaris, central Oklahoma. Copeia 2000: 3, 786-791.

Hutchison D. W. (1997) Population genetic consequences of the Holocene invasion of the Ozarks and Flint Hills by the eastern collared lizard (Crotaphytus collaris collaris) with subsequent habitat fragmentation. PhD Thesis, Washington University in St. Louis.

Hutchison D. W. (2003) Testing the central/peripheral model: Analyses of microsatellite variability in the eastern collared lizard (Crotaphytus collaris collaris). American Midland Naturalist, 149, 148-162.

Lewis P. O., Zaykin D. (1996) Genetic Data Analysis, v, 1.0 (d6) for Windows 95/NT. Available at: http:/ / lewis.eeb.uconn. edu/lewishome

McGuire J. A. (1996) Phylogenetic Systematics of Crotaphytid Lizards (Reptilia: Iguania: Crotaphytidae). Bulletin of the Carnegie Museum of Natural History, Number. 32. Carnegie Institute, Pittsburgh, USA.

Rice W. R. (1989) Analyzing tables of statistical tests. Evolution, 43, 223-225.

Sambrook J., Fritsch E., Maniatis T. (1989) Molecular Cloning. A Laboratory Manual, 2nd ed. Cold Spring Harbor Laboratory, New York.

Templeton A. R., Robertson R. J., Brisson J., Strasburg J. (2001) Disrupting evolutionary processes: The effect of habitat fragmentation on collared lizards in the Missouri Ozarks. Proceedings of the National Academy of Sciences of the USA, 98, 5426-5432.

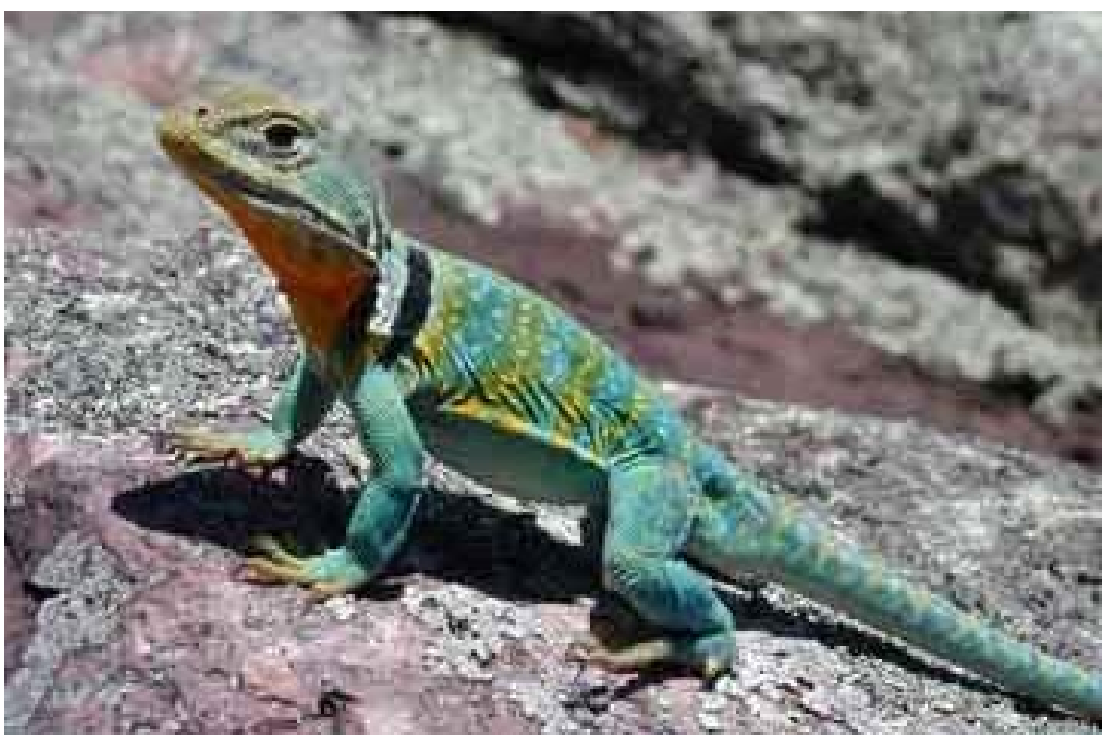

Crotaphytus collaris, Stegall Mountain, Missouri (Alan Templeton \& National Park Service) 